\title{
ISOLASI ALBUMIN DAN KARAKTERISTIK BERAT MOLEKUL HASIL EKSTRAKSI SECARA PENGUKUSAN IKAN GABUS (Ophiocephalus striatus)
}

\author{
Oleh: \\ Matheus Nugroho*) \\ *) Tenaga Pengajar Universitas Yudharta Pasuruan
}

\begin{abstract}
Abstrak
Tujuan penelitian ini untuk adalah isolasi albumin dan penentuan berat molekul dari ekstraksi secara pengukusan ikan gabus (Ophiocephalus striatus). Metode penelitian adalah ekstraksi secara pengukusan waterbath dengan suhu kisaran $40-90^{\circ} \mathrm{C}$, dan lama 25-35 menit, untuk mendapatkan rendemen dan kadar albumin ekstrak kasar ikan gabus yang optimal. Tahap selanjutnya adalah isolasi albumin dan penentuan berat molekulnya dari hasil ekstraksi yang optimal. Analisa data penelitian ini adalah analisa deskriptif untuk melihat foto hasil elektroforesis. Sementara untuk hasil analisa pengukuran isolasi albumin secara filtrasi gel sephadex G-75 dilakukan dengan Rancangan Petak terbagi (RPB). Hasil penelitian menunjukkan bahwa ada interaksi antara berbagai faktor perlakuan. Kadar albumin isolat albumin tertinggi sebesar $1,77 \mathrm{mg} / \mathrm{g}$, pengaruh suhu pengukusan $40^{\circ} \mathrm{C}$ selama 30 menit, pada pengambilan $5 \mathrm{ml}$ fraksi ke-2. Elektroforesis SDS-PAGE dengan jumlah protein paling komplek adalah isolat albumin pengaruh suhu pengukusan $40^{\circ} \mathrm{C}$ selama 30 menit, terletak pada $5 \mathrm{ml}$ fraksi ke-1, $5 \mathrm{ml}$ fraksi ke-2 dan $5 \mathrm{ml}$ fraksi ke-3. Pita protein terdiri dari 2 pita mayor dan 5 pita minor dengan berat molekul 14,6-133 $\mathrm{kD}$.
\end{abstract}

Kata kunci : ikan gabus (Ophiocephalus striatus), isolasi albumin, berat molekul

\begin{abstract}
Theobjective of this study for the isolation of albumin and determination of molecular weight of extraction by steaming of fish gabus (Ophiocephalus striatus). The research method is the extraction of a steaming waterbath with the temperature range $40-90^{\circ} \mathrm{C}$, and the long $25-35$ minutes, to obtain recovery and albumin levels of crude extract of fish gabus that optimal. The next stage is the isolation of albumin and its molecular weight determination of the optimal extraction. Analysis of data of this study is a descriptive analysis to see photos of electrophoresis. While analyzing the results of measurements for albumin isolation by gel filtration Sephadex G-
\end{abstract}




\section{Jurnal Teknologi Pangan Vol.4 No.1 \\ November2012}

75 made with split plot design (RPB). The results showed that there is interaction between the various treatment factors. The highest levels of albumin albumin isolates of $1.77 \mathrm{mg} / \mathrm{g}$, the effect of steaming temperature of $40^{\circ} \mathrm{C}$ for 30 minutes, $5 \mathrm{ml}$ fractions on the uptake-2. SDS-PAGE electrophoresis with the most complex of the protein albumin is isolate the influence of steaming temperature $40^{\circ} \mathrm{C}$ for 30 minutes, located at $5 \mathrm{ml}-1$ fraction, $5 \mathrm{ml}$ of fraction- 2 and $5 \mathrm{ml}$ fractions to-3. Protein bands consist of two major bands and 5 minor bands with moleculer weight 14.6 to $133 \mathrm{kD}$.

Key words: fish gabus (Ophiocephalus striatus), albumin isolation, molecular weight

\section{PENDAHULUAN}

Albumin merupakan protein plasma yang paling tinggi jumlahnya sekitar $60 \%$ dan memiliki berbagai fungsi yang sangat penting bagi kesehatan yaitu pembentukan jaringan sel baru, mempercepat pemulihan jaringan sel tubuh yang rusak serta memelihara keseimbangan cairan di dalam pembuluh darah dengan cairan di dalam rongga interstitial dalam batas-batas normal, kadar albumin dalam darah 3,5-5 g/dl. Kekurangan albumin dalam serum dapat mempengaruhi pengikatan dan pengangkutan senyawasenyawa endogen dan eksoden, termasuk obat-obatan, karena seperti diperkirakan distribusi obat keseluruh tubuh itu pengikatannya melalui fraksi albumin (Goldstein et al., 1968; Vallner, 1977; Tandra et al., 1988).
Pengadaan albumin terutama untuk kasus bedah saat ini mencapai 91\%, 2/3 albumin tersebut dipakai di bagian bedah dan sisanya $1 / 3$ bagian dipergunakan untuk penanganan penyakit dalam. Harga serum albumin untuk infus mencapai kurang lebih Rp. 1.500.000,- per botol kemasan 100 ml-20\% albumin (Alexander et al., 1979; Tullis, 1997).

Ikan gabus merupakan ikan yang mempunyai kandungan kadar albumin yang cukup tinggi. Hasil penelitian Suprayitno (2003) pernah diujicobakan di instalasi gizi serta bagian bedah RSU dr Saiful Anwar Malang. Uji coba tersebut dilakukan pada pasien pascaoperasi dengan kadar albumin rendah $(1,8$ $\mathrm{g} / \mathrm{dl}$ ). Dengan perlakuan $2 \mathrm{~kg}$ ikan gabus masak per hari, telah meningkatkan kadar albumin darah pasien menjadi normal (3,5-5,5 
g/dl). Caranya, daging ikan gabus dikukus atau di-steam sehingga memperoleh filtrate, yang dijadikan menu ekstra bagi penderita hipoalbumin dan luka. Pemberian menu ekstrak filtrat ikan gabus tersebut berkorelasi positif dengan peningkatan kadar albumin plasma dan penyembuhan luka pascaoperasi.

Pengaruh perlakuan suhu tinggi menyebabkan perubahan melemahnya enzim proteinase dan nilai daya cerna protein (Nielsen, 1998). Menurut Stryer (1968), Slavik (1982) dan Arakawa et al. (1991) dalam Folawiyo and Apenten (1996), menjelaskan bahwa perlakuan panas pada albumin akan menghasilkan perubahan struktur yang tidak dapat balik (irreversible), yang terlihat dengan meningkatnya protein yang tidak larut dalam air. Pengaruh perlakuan panas pada struktur albumin juga dapat albumin, sehingga diperlukan panas yang tepat pada struktur protein tersebut (Stryer, 1968; Slavik, 1982; Arakawa et al., 1991; Wicker et al., 1986 dan Arntfield et al., 1989 dalam Folawiyo and Apenten, 1996).

Berdasarkan hasil penelitian pada ikan gabus dan ikan tomang didapatkan kadar albumin sebesar $1332,7 \mathrm{mg} / 100 \mathrm{~g}$ dan 1188,05 mg/100 g (Carvallo, 1998). Analisa kadar albumin pada filtrat ikan gabus hasil pengukusan suhu $98^{\circ} \mathrm{C}$ adalah 19,4\% (Martini, 1998). Hasil analisa sterilisasi ikan gabus pada suhu $121{ }^{\circ} \mathrm{C}$ selama 25 menit didapatkan kadar albumin filtrat adalah $116,419 \pm 22,660 \mathrm{mg} / 100 \mathrm{~g}$ (Hidayati, 1999). Berdasarkan data hasil penelitian tersebut diatas memperkuat untuk memperoleh isolat albumin dan karakteristik berat molekul hasil ekstraksi secara pengukusan ikan gabus, sebagai pengganti serum albumin dalam upaya membantu mempertahankan dan meningkatkan nilai gizi dan kesehatan manusia.

\section{Materi dan Metode}

Peralatan yang dipergunakan pembuatan ekstrak kasar ikan gabus antara lain : pisau, gunting, waterbath, thermokopel, thermometer $100^{\circ} \mathrm{C}$, timbangan gelas ukur, kain saring, plastik dan press hidrolik. Peralatan untuk analisa kadar albumin antara lain : kuvet diameter $1 \mathrm{~cm}$, Shimadzu spectrophotometer UV-100-02 dan spectrophotometer autoanalyzer. Peralatan untuk pemurnian ekstrak kasar albumin adalah kolom filtrasi gel ukuran $(2,5 \times 60 \mathrm{~cm})$ dengan bahan isian sephadex G-75 untuk memurnikan ekstrak kasar albumin. Pendeteksian berat molekul albumin, peralatannya 1 unit 
elektroforesis apparatus merk BioRad yang dihubungkan dengan power supply berkekuatan 300 volt dan $120 \mathrm{~mA}$, dan ditempatkan pada refrigerator, preparasi sampel meliputi (sampel plate, scapel, pinset, deep freezer, mistar, pipet, pisau, dan neraca digital), penyiapan gel (gelas ukur, erlenmeyer, neraca digital, pipet, pemanas, sarung tangan, kaca, plastik tipis, gel plate dan vacum pump), pewarnaan (peralatan yang digunakan pemotong, kaca, mika tipis, pemberat, pipet, neraca digital, gel plate dan incubator), pembuatan buffer (peralatan yang digunakan gelas ukur, pipet dan erlenmeyer).

Bahan-bahan yang digunakan untuk ekstraksi adalah ikan gabus yang diperoleh dari bendungan Karangkates dalam keadaan hidup dan aquadest. Bahan untuk uji kadar albumin menggunakan metode brom cresol green adalah buffer succinate (7 mmol/l pH 4,2), brom cresol green $0,15 \mathrm{mmol} / \mathrm{l}$, brij 35 dan aquadest dapar succinate (0,01 M; pH 4,2), untuk kadar albumin setelah pemurnian kolom filtrasi gel pengujiannya dengan $\mathrm{UV}$, bahannya antara lain BSA standar 0,5 g/l, buffer phosphat 0,1 M pH 7,1 dan aquadest. Sementara untuk pemurnian ekstrak kasar albumin bahan-bahan yang digunakan terdiri dari $1 \mathrm{~g}$ sephadex
G-7, buffer phosphat $(0,1 \mathrm{M} \mathrm{pH}$ 7,1), glasswool dan natrium azid $0,2 \%$. Bahan analisa elektroforesis meliputi : gel pemisah $12,5 \%$ (acrylamid $30 \% \quad 4,126 \mathrm{ml}, 1,5 \mathrm{M}$ tris $\mathrm{pH} \quad 8,82,5 \mathrm{ml}, 10 \%$ SDS 100 $\mu 1$, TEMED $20 \mu 1,10 \%$ amonium persulfat $25 \mu \mathrm{l}$ ), gel penumpuk $4 \%$ (acrylamid 30\% 1,03 ml, 0,5 $\mathrm{m}$ tris pH 6,8 $\mathrm{H}_{2} \mathrm{O} 2,650 \mathrm{ml}, 10 \%$ SDS 50 $\mu \mathrm{l}, 10 \%$ amonium persulfat $15 \mu \mathrm{l}$ ), running buffer (glycine 14,4 g, tris base $1,0 \mathrm{~g}$, ad aquadest $100 \mathrm{ml}$ ), reducing sampel buffer (RBS) $\left(\mathrm{H}_{2} \mathrm{O}\right.$ (aqua bid) $3 \mathrm{ml}, 0,5 \mathrm{M}$ tris $\mathrm{pH} \mathrm{6,8} 1$ $\mathrm{ml}$, glycerol $10 \% 1,6 \mathrm{ml}$, SDS $10 \%$ $1,6 \mathrm{ml}$, mercaptoetanol $0,4 \mathrm{ml}$ dan bromophenol blue 0,4 $\mathrm{ml}$ ), bahan pewarnaan (stainning) (comassie brilliant blue $0,1 \mathrm{~g}$, methanol absolut $40 \mathrm{ml}$, asam asetat $10 \mathrm{ml}$, dan ad aquadest $100 \mathrm{ml}$ ), destainning (methanol $20 \mathrm{ml}$, asam asetat $10 \mathrm{ml}$ dan ad aquadest 100 $\mathrm{ml})$.

Tujuan penelitian adalah isolasi albumin dan karakteristik berat molekul hasil ekstraksi secara pengukusan ikan gabus (Ophiocephalus striatus). Prosedur penelitian pada tahap I meliputi : pemurnian dengan Kromatografi kolom Filtrasi-Gel (Modifikasi kato et al., 1981); pendeteksian berat molekul albumin (Hames and Rickwood, 1990).

Analisa data yang digunakan dalam penelitian adalah deskriptif 
kualitatif untuk melihat foto hasil elektroforesis. Sedangkan untuk hasil analisa pengukuran pemurnian secara filtrasi gel sephadex G-75 dilakukan dengan Rancangan Petak Terbagi (RPB).

\section{Hasil dan Pembahasan}

Secara umum kadar albumin isolat albumin ikan gabus berkisar antara 0,26-1,77 mg/g. Korelasi antara suhu pengukusan waterbath dengan kadar albumin isolat albumin ikan gabus mengikuti persamaan regresi $\mathrm{Y}=-0,02 \mathrm{x}+$ 2,7381 dengan nilai $\mathrm{r}=0,905$, sementara untuk fraksinasi kadar albumin isolat albumin ikan gabus persamaan regresi $\mathrm{Y}=-0,0725 \mathrm{x}^{2}+$ $0,3575 \mathrm{x}+0,9725$ dengan nilai $\mathrm{r}=$ 0,997. Berdasarkan tingkat korelasinya $\left(\mathrm{R}^{2}\right)$, maka perlakuan suhu pengukusan dan fraksinasi berpengaruh besar terhadap kadar albumin isolat albumin ikan gabus.
Gambar 1. menunjukan bahwa kadar albumin ikan gabus tertinggi untuk tiap-tiap perlakuan suhu pengukusan $40-90^{\circ} \mathrm{C}$, dengan lama pengukusan 30 menit, terdapat pada $5 \mathrm{ml}$ fraksi ke-2 dan $5 \mathrm{ml}$ fraksi ke3. Berdasarkan hasil tersebut maka diduga bahwa molekul-molekulmolekul kecil, termasuk dalam hal ini albumin masuk pori-pori gel, sementara molekul yang lebih besar akan ditolak, sehingga molekul besar akan berada dalam fase mobil dan melewati partikel-partikel gel sephadex G-75.

Soemitro et al. (1992), menyatakan kecepatan pergerakan molekul-molekul besar ini sangat tergantung pada berat molekulnya. Protein yang mempunyai berat molekul besar akan lebih dulu keluar sebagai eluat, dan diikuti oleh protein yang memiliki berat molekul lebih rendah. 


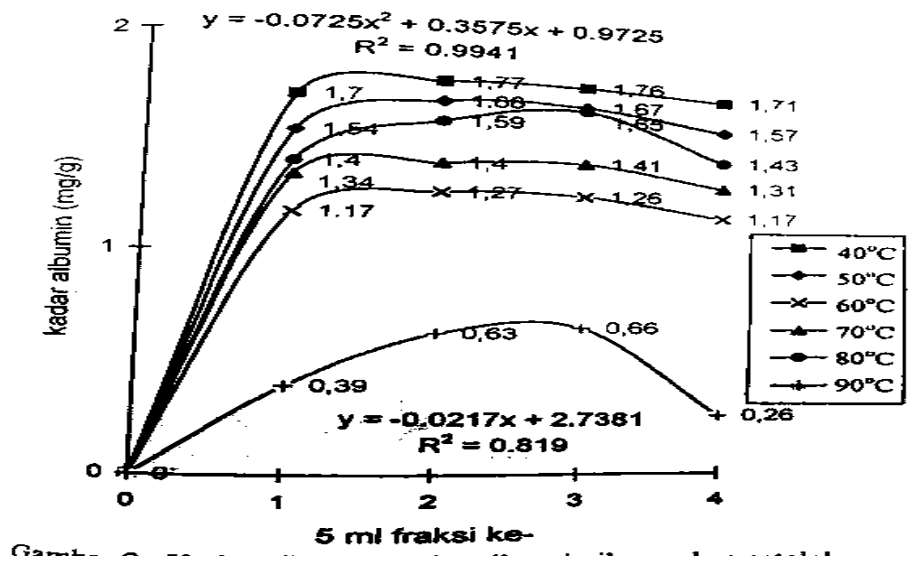

Gambar 1.Kadar albumin isolat albumin ikan gabus setelah pemurnian kolom filtrasi gel sephadex G-75

Hasil uji F menunjukkan bahwa pengaruh suhu pengukusan waterbath dan fraksinasi, dan interaksinya terhadap kadar albumin isolat albumin berpengaruh sangat nyata. Hasil analisis lanjut dengan uji BNT $(\alpha=0,01)$ disajikan pada Tabel 1. Hasil uji BNT menunjukkan bahwa kadar albumin isolat albumin tertinggi oleh pengaruh suhu pengukusan waterbath sebesar $1,74 \mathrm{mg} / \mathrm{g}$, dengan suhu waterbath $40^{\circ} \mathrm{C}$ (suhu daging $\left.36^{\circ} \mathrm{C}\right)$. Diduga hal ini berkaitan dengan kelarutan albumin yang cenderung belum turun dan kerusakannya relatif belum terjadi. Secara visual tampak partikelpartikel isolat albumin tidak terpisah dan mengendap bila dibiarkan, kekuatan ketegangan antar partikel masih kuat, tetapi kekentalan belum terjadi. Karakteristik fisik memudahkan fraksinasi filtrasi gel, sebab proses elusinya akan lebih mudah. Pada umumnya kelarutan protein naik pada suhu $0-40^{\circ} \mathrm{C}$, tetapi suhu diatas $40^{\circ} \mathrm{C}$ kebanyakan protein menjadi tidak stabil, dan ditandai perubahan sifat fisik protein. Sifat fisik sangat berpengaruh terhadap sifat fungsional protein, karena mempengaruhi interaksi protein dengan pelarut air, dan kemampuan mengikat air oleh daging (Wirahadikusuma, 1981; 
Damodaran, 1996 dalam Nakai and Modler, 1996).

Kadar albumin dengan

tergantung

kemampuan antara,

kecepatan pada tingkat sephadex G-75. Kato et al. (1981), menyatakan bahwa molekulmolekul protein terlarut akan menembus jaringan gel dalam jumlah banyak atau sedikit tergantung dari bentuk molekulnya, dan ikatan-ikatan yang terjadi dengan molekul gelnya sendiri, sehingga besar dan bentuk dari molekul zat terlarut akan menentukan pembagian antara zat yang masuk dalam molekul gel dan yang ikut fase mobil. molekul menengah akan mengalir

Tabel 1. Kadar albumin isolat albumin ikan gabus karena pengaruh perlakuan suhu pengukusan waterbath dan proses fraksinasi

\begin{tabular}{|c|c|}
\hline Pengaruh suhu pengukusan waterbath $\left({ }^{\circ} \mathrm{C}\right)$ & Kadar albumin $(\mathrm{mg} / \mathrm{g})$ \\
\hline 40 & $1,74 \mathrm{e}$ \\
50 & $1,62 \mathrm{~d}$ \\
60 & $1,52 \mathrm{c}$ \\
70 & $1,37 \mathrm{~b}$ \\
80 & $1,22 \mathrm{~b}$ \\
90 & $0,49 \mathrm{a}$ \\
\hline BNT $(\alpha=0,01)$ & 0,1758 \\
\hline Pengaruh fraksinasi $(5 \mathrm{ml}$ fraksi ke- $)$ & Kadar albumin $(\mathrm{mg} / \mathrm{g})$ \\
\hline 1 & $1,26 \mathrm{a}$ \\
3 & $1,39 \mathrm{bc}$ \\
4 & $1,40 \mathrm{c}$ \\
BNT $(\alpha=0,01)$ & $1,24 \mathrm{a}$ \\
\hline
\end{tabular}

Keterangan: angka kadar albumin yang diikuti dengan huruf yang sama pada kolom yang sama, menunjukkan hasil tidak berbeda nyata pada uji BNT $(\alpha=0,01)$ 
Tabel 2. Kadar albumin isolat albumin ikan gabus karena pengaruh suhu pengukusan waterbath $\left({ }^{\circ} \mathrm{C}\right)$ dengan fraksinasi

\begin{tabular}{|c|c|c|}
\hline \multicolumn{3}{|c|}{ Interaksi suhu pengukusan waterbath dengan fraksinasi } \\
\hline Suhu waterbath $\left({ }^{\circ} \mathrm{C}\right)$ & $5 \mathrm{ml}$ fraksi ke- & Kadar Albumin $(\mathrm{mg} / \mathrm{g})$ \\
\hline 40 & 1 & $1,70 \mathrm{~h}$ \\
& 2 & $1,77 \mathrm{j}$ \\
& 3 & $1,76 \mathrm{ij}$ \\
& 4 & $1,71 \mathrm{~h}$ \\
\hline 50 & 1 & $1,54 \mathrm{fg}$ \\
& 2 & $1,68 \mathrm{~h}$ \\
& 3 & $1,67 \mathrm{~h}$ \\
& 4 & $1,57 \mathrm{~g}$ \\
\hline 60 & 1 & $1,40 \mathrm{f}$ \\
& 2 & $1,59 \mathrm{~g}$ \\
& 3 & $1,65 \mathrm{gh}$ \\
& 4 & $1,43 \mathrm{f}$ \\
\hline 70 & 1 & $1,34 \mathrm{f}$ \\
& 2 & $1,40 \mathrm{f}$ \\
& 3 & $1,41 \mathrm{f}$ \\
& 4 & $1,31 \mathrm{e}$ \\
\hline 80 & 1 & $1,17 \mathrm{e}$ \\
& 2 & $1,27 \mathrm{e}$ \\
& 3 & $1,26 \mathrm{e}$ \\
& 4 & $1,17 \mathrm{de}$ \\
\hline 90 & 1 & $0,39 \mathrm{a}$ \\
& 2 & $0,63 \mathrm{bc}$ \\
& 3 & $0,66 \mathrm{c}$ \\
& & $0,26 \mathrm{a}$ \\
\hline & & 0,2012 \\
\hline
\end{tabular}

Keterangan: angka kadar albumin yang diikuti dengan huruf yang sama pada kolom yang sama, menunjukkan hasil tidak berbeda nyata pada uji BNT $(\alpha=0,01)$

Hasil uji BNT $(\alpha=0,01)$ Tabel albumin isolat albumin optimal 2. menunjukkan interaksi pengaruh sebesar $1,77 \mathrm{mg} / \mathrm{g}$, oleh pengaruh suhu pengukusan waterbath pada suhu waterbath $40^{\circ} \mathrm{C}$ (suhu daging seluruh fraksi dengan kadar $36^{\circ} \mathrm{C}$ ) dan terletak pada $5 \mathrm{ml}$ fraksi 
ke-2. Optimalnya kadar albumin tersebut diduga pada suhu pengukusan waterbath $40^{\circ} \mathrm{C}$ belum terjadi perubahan secara besar terhadap sifat karakteristik protein daging ikan, dan kelarutan protein dalam isolat albumin relatif tinggi. Hal ini dibuktikan dari karakteristik fisik isolat albumin yang secara visual tampak belum terjadi penggumpalan. Kondisi tersebut akan mempermudah fraksinasi kolom filtrasi gel, sebab partikelpartikel yang terlarut dalam isolat albumin ukuran dan bentuknya relatif tidak terlalu besar dari poripori gel, proses elusi akan lancar dan tidak tertahan di permukaan gel sephadex G-75. Namun sebaliknya jika partikel-partikel yang terlarut dalam isolat albumin lebih besar, maka proses elusi akan tertahan, dan dapat merusak gel sephadex itu sendiri, sebab partikel-partikel tersebut mendukung sekali untuk pertumbuhan bakteri.

Foegeding et al. (1996), menjelaskan pemanasan albumin suhu $<50^{\circ} \mathrm{C}$ tidak menurunkan kelarutannya, albumin mulai turun kelarutannya pada suhu antara 50$70^{\circ} \mathrm{C}$, yang ditandai terbentuknya gel, kelarutan menurun secara besar pada suhu $70-80^{\circ} \mathrm{C}$, ditandai gel albumin terbentuk secara kuat.

Kecenderungan kadar albumin optimal terdapat pada pengambilan $5 \mathrm{ml}$ fraksi ke-2, hal ini diduga karena molekul-molekul bukan albumin $\mathrm{u}=$ yang lebih besar dari ukuran pori-pori sephadex G-75 telah membengkak sebagai akibat pengaruh pemanasan dan tidak dapat masuk dalam partikel-partikel gel. Molekul-molekul tersebut bersama cairan bufer akan mengalir melalui rongga-rongga antar partikel sephadex G-75, sehingga moleku-molekul yang bukan albumin akan lebih dulu keluar, dan terdapat pada pengambilan $5 \mathrm{ml}$ fraksi ke-1. Sudarmadji (1996), menjelaskan hasil penelitiannya bahwa molekul-molekul kecil akan masuk dalam partikel gel, dan akan ikut mengalir dengan cairan dengan kecepatan yang tergantung pada ukuran dan bentuknya. Kato et al. (1981), menjelaskan hasil fraksinasi ovalbumin putih telur pengaruh freeze-dried suhu $50^{\circ} \mathrm{C}$, dengan ratarata konsentrasi ovalbumin (\%) tertinggi terdapat pada fraksi II dan III, sementara fraksi I, IV dan V cenderung menurun konsentrasi ovalbumin.

\section{Pendeteksian Berat Molekul Albumin dengan SDS-PAGE}

Hasil elektroforesis yang tersaji pada Gambar 2. menunjukkan bahwa isolat albumin perlakuan suhu pengukusan waterbath $80^{\circ} \mathrm{C} \quad$ (suhu daging $55^{\circ} \mathrm{C}$ ), dan dilanjutkan fraksinasi kolom filtrasi gel sephadex G-75 
untuk pengambilan $5 \mathrm{ml}$ fraksi ke-2 setelah

dielektroforesis

menghasilkan enam pita protein, terdiri dari dua pita mayor yaitu pita 5 dan 8 dengan berat molekul 66,3 $\mathrm{kD}$ dan 11,2 kD, dan empat pita minor yaitu pita 1, 2, 3 dan 4 dengan berat molekul 145,3 kD, $115,1 \mathrm{kD}, 108,5 \mathrm{kD}$ dan $81,1 \mathrm{kD}$; untuk $5 \mathrm{ml}$ fraksi ke-3 setelah dielektroforesis menghasilkan lima pita protein, yang terdiri dari dua pita mayor yaitu pita 5 dan 8 dengan berat molekul $66,3 \mathrm{kD}$ dan $11,2 \mathrm{kD}$, dan tiga pita minor yaitu pita 2, 3, dan 4 dengan berat molekul masing-masing sekitar $121,9 \mathrm{kD}, 102,4 \mathrm{kD}$ dan $85,9 \mathrm{kD}$; sedangkan untuk $5 \mathrm{ml}$ fraksi ke-4 setelah dielektroforesis menghasilkan empat pita protein, yang terdiri dari dua pita mayor yaitu pita 5 dan 8 dengan berat molekul $66,2 \mathrm{kD}$ dan $11,2 \mathrm{kD}$, dan dua pita minor yaitu pita 2 dan 3 dengan berat molekul $121,9 \mathrm{kD}$ dan $108,5 \mathrm{kD}$.

Hasil elektroforesis tersebut menunjukkan bahwa dari 3 fraksi pengambilan kolom filtrasi gel sephadex G-75 setelah melalui elektroforesis menghasilkan pitapita protein pada elektroforegram poliakrilamid SDS adalah pada fraksi ke-2 sampai ke-4, hal tersebut dapat dilihat pada lajur B, C, dan D Gambar 2. Pada fraksi ke2 sampai ke-4 ketebalan pita

protein yang hampir sama, maka diduga pada $5 \mathrm{ml}$ fraksi ke-2,5 ml fraksi ke-3dan $5 \mathrm{ml}$ fraksi ke-4 mempunyai kesamaan dalam hal jumlah kandungan albumin yang terlarut. Isolat albumin hasil fraksinasi kolom filtrasi gel dengan kandungan albumin relatif sama pada pengambilan $5 \mathrm{ml}$ fraksi ke-2 sampai dengan $5 \mathrm{ml}$ fraksi ke-4.

Kato

menjelaskan

ovalbumin putih telur, rata-rata konsentrasi ovalbumin (\%) tertinggi terdapat pada fraksi II dan III, sementara fraksi I, IV dan V cenderung menurun konsentrasi ovalbumin. Sutiman et al. (1996) memaparkan hasil penelitiannya bahwa molekul protein dengan muatan dan ukuran yang sama akan terakumulasi pada zona atau pita yang berdekatan. Lebih lanjut dijelaskan, bahwa pita yang lebih banyak menunjukkan bahwa sampel tersusun atas protein komplek.

Hasil elektroforesis pada Gambar 2. isolat albumin perlakuan suhu pengukusan waterbath $60^{\circ} \mathrm{C}$ (suhu daging $45^{\circ} \mathrm{C}$ ), selanjutnya dilakukan fraksinasi kolom filtrasi gel sephadex G-75, pada pengambilan $5 \mathrm{ml}$ fraksi ke-1, menghasilkan enam pita protein yang terdiri dari dua pita mayor yaitu pita 5 dan pita 8 dengan berat molekul $66,3 \mathrm{kD}$ dan $11,2 \mathrm{kD}$, dan 
empat pita minor yaitu fraksi 1, 2, 3 dan 4 dengan berat molekul sekitar $145,3 \mathrm{kD}, 115,1 \mathrm{kD}, 102,4 \mathrm{kD}$ dan $85,9 \mathrm{kD}$; untuk $5 \mathrm{ml}$ fraksi ke-2 setelah dielektroforesis menghasilkan enam pita protein yang terdiri dari satu pita mayor yaitu pita 8 dengan berat molekul $11,2 \mathrm{kD}$, serta lima pita minor yaitu pita 1, 2, 3, 4 dan 5 dengan berat molekul masing-masing adalah $154,2 \mathrm{kD}, 121,9 \mathrm{kD}, 102,4 \mathrm{kD}, 85,9$ $\mathrm{kD}$ dan $66,3 \mathrm{kD}$; untuk $5 \mathrm{ml}$ fraksi ke-3 setelah dielektroforesis menghasilkan enam pita protein, terdiri dari dua pita mayor yaitu pita 5 dan 8 dengan berat molekul 66,2 $\mathrm{kD}$ dan $13,3 \mathrm{kD}$, serta empat pita minor yaitu 1, 2, 3 dan 4 dengan berat molekul masing-masing adalah 154,2 kD, 129,3 kD, 108,5 $\mathrm{kD}$ dan $85,9 \mathrm{kD}$; sementara untuk 5 $\mathrm{ml}$ fraksi ke-4 setelah dielektroforesis menghasilkan enam pita protein yang terdiri dari dua pita mayor yaitu pita 5 dan 8 dengan berat molekul $66,3 \mathrm{kD}$ dan $14,1 \mathrm{kD}$, serta empat pita minor yaitu 1, 2, 3 dan 4 dengan berat molekul masing-masing $154,2 \mathrm{kD}$, $121,9 \mathrm{kD}, 108,5 \mathrm{kD}$ dan $81,1 \mathrm{kD}$. Berdasarkan elektroforesis hasil tersebut menunjukkan bahwa isolat albumin perlakuan suhu pengukusan waterbath $60^{\circ} \mathrm{C}$ (suhu daging $45^{\circ} \mathrm{C}$ ), jumlah kandungan protein terlarut untuk setiap fraksi dari kolom gel sephadex G-75 masih tinggi. Hal ini dibuktikan dengan jumlah pita protein pada keempat fraksi adalah hampir sama (lajur E, F, $G$ dan $H$ pada Gambar 2.). Melihat hal tersebut, maka diduga isolat albumin hasil pengukusan suhu waterbath $60^{\circ} \mathrm{C}$, di albumin plasmanya belum terjadi denaturasi. Kandungan albumin tertinggi terjadi pada $5 \mathrm{ml}$ fraksi ke-1, $5 \mathrm{ml}$ fraksi ke-3 dan $5 \mathrm{ml}$ fraksi ke-4, hal ini terlihat dari kondisi ketebalan pita protein yang hampir sama pada pita ketiga fraksi tersebut (lajur E, G dan $H$ pada Gambar 6.), dan ketebalan terletak pada pita protein 5 dengan berat molekul 66,2-66,3 kD. Raeker and Johson (1995), menyatakan hasil penelitiannya bahwa terjadinya permulaan denaturasi albumin plasma adalah pada suhu pemanasan $69,1 \pm 0,3^{\circ} \mathrm{C}$, sementara puncak denaturasi plasma terjadi pada suhu pemanasan $78 \pm 0,2^{\circ} \mathrm{C}$. 


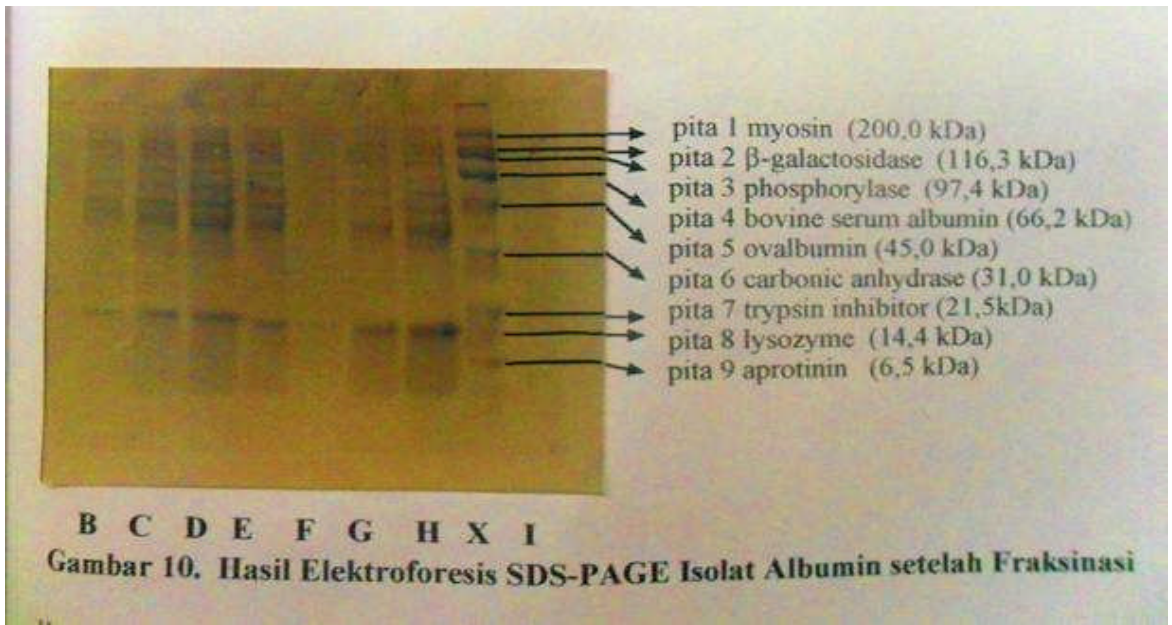

Gambar 2. Hasil Elektroforesis SDS-PAGE Isolat Albumin setelah Fraksinasi

Keterangan :

$\mathrm{X}=$ kit penciri protein : myosin, $\beta$-galactosidase, phosporylase $\mathrm{B}$, bovine serum albumin, ovalbumin, carbonic anhydrase, trypsin inhibitot, lysozyme dan aprotinin

$\mathrm{B}=$ isolat albumin $5 \mathrm{ml}$ fraksi ke-2 suhu waterbath $80^{\circ} \mathrm{C}$ (suhu daging $55^{\circ} \mathrm{C}$ )

$\mathrm{C}=$ isolat albumin $5 \mathrm{ml}$ fraksi ke-3 suhu waterbath $80^{\circ} \mathrm{C}$ (suhu daging $55^{\circ} \mathrm{C}$ )

$\mathrm{D}=$ isolat albumin $5 \mathrm{ml}$ fraksi ke-4 suhu waterbath $80^{\circ} \mathrm{C}$ (suhu daging $55^{\circ} \mathrm{C}$ )

$\mathrm{E}=$ isolat albumin $5 \mathrm{ml}$ fraksi ke-1 suhu waterbath $60^{\circ} \mathrm{C}$ (suhu daging $45^{\circ} \mathrm{C}$ )

$\mathrm{F}=$ isolat albumin $5 \mathrm{ml}$ fraksi ke-2 suhu waterbath $60^{\circ} \mathrm{C}$ (suhu daging $45^{\circ} \mathrm{C}$ )

$\mathrm{G}=$ isolat albumin $5 \mathrm{ml}$ fraksi ke-3 suhu waterbath $60^{\circ} \mathrm{C}$ (suhu daging $45^{\circ} \mathrm{C}$ )

$\mathrm{H}=$ isolat albumin $5 \mathrm{ml}$ fraksi ke-4 suhu waterbath $60^{\circ} \mathrm{C}$ (suhu daging $45^{\circ} \mathrm{C}$ )

$\mathrm{I}=$ isolat albumin $5 \mathrm{ml}$ fraksi ke-1 suhu waterbath $90^{\circ} \mathrm{C}$ (suhu daging $66^{\circ} \mathrm{C}$ )

Hasil Elektroforesis (Gambar pita protein. Hasil elektroforesis 2.) isolat albumin perlakuan suhu (Gambar 2.) isolate albumin pengukuran waterbath $90^{\circ} \mathrm{C}$ (suhu perlakuan suhu pengukuran daging $66^{\circ} \mathrm{C}$ ), dan dilanjutkan waterbath $90^{\circ} \mathrm{C}$ (suhu daging fraksinasi kolom fitrasi gel $60^{\circ} \mathrm{C}$ ), dan dilanjutkan fraksinasi sephadex G-75 untuk pengambilan kolom filtrasi gel sephadex G-75 $5 \mathrm{ml}$ fraksi ke-1 tidak didapatkan untuk $5 \mathrm{ml}$ fraksi ke-2, tidak 
didapatkan pita protein. Begitu juga untuk pengambilan $5 \mathrm{ml}$ fraksi ke-3 dan 4 pada suhu pemanasan yang sama setelah dielektroforesis tidak menghasilkan pita protein.

Hasil elektroforesis tersebut menunjukan bahwa isolate albumin perlakuan suhu pengukusan waterbath $90^{\circ} \mathrm{C}$ (suhu daging $66^{\circ} \mathrm{C}$ ), jumlah kandungan dan kualitas protein yang terlarut dalam isolate albumin adalah rendah, diduga pada suhu pengukuran waterbath $90^{\circ} \mathrm{C}$ protein sudah mengalami denaturasi. Keempat fraksi hasil kolom filtrasi gel sephadex G-75, setelah dielektroforesis tidak satupun pita protein terdeteksi (lihat lajur I Gambar 2., lajur J, K dan L Gambar 3.).

Weissler et al. (1981) menjelaskan dalam penelitiannya, bahwa ketika BSA dan alphalactalbumin dipanaskan pada suhu $78^{\circ} \mathrm{C}$ selama 15 menit, maka akan menurunkan jumlah zone yang terdeteksi. Foegeding et al. (1986) memaparkan juga hasil penelitiannya, bahwa pada pemanasan lebih dari $90^{\circ} \mathrm{C}$ albumin mulai mencapai gel maksimum. Lebih lanjut diterangkan pada suhu $70^{\circ} \mathrm{C}$ kelarutan albumin berkisar $81 \%$ sehingga suhu pengukusan waterbath $90^{\circ} \mathrm{C}$ akan menurunkan kelarutan albumin dalam isolate albumin ikan gabus.

Hasil elektroforesis ( Gambar 3.) isolate albumin perlakuan suhu pengukusan waterbath $40^{\circ} \mathrm{C}$ (suhu daging $36^{\circ} \mathrm{C}$ ), dan dilanjutkan fraksinasi kolom filtrasi gel sephadex G-75, untuk pengambilan $5 \mathrm{ml}$ fraksi ke-1, didapatkan tujuh pita protein, terdiri dari dua pita mayor yaitu pita 5 dan 8 dengan berat molekul $66,2 \mathrm{kD}$ dan $14,6 \mathrm{kD}$, dan lima pita minor yaitu 1, 2, 3, 4 dan 6 dengan berat molekul masing-masing berturut-turut 133 $\mathrm{kD}, 108,8 \mathrm{kD}, 103,5 \mathrm{kD}, 84,7 \mathrm{kD}$ dan $37,9 \mathrm{kD}$; untuk $5 \mathrm{ml}$ fraksi ke2, setelah dielektroforesis didapatkan tujuh pita protein, terdiri dari dua pita mayor yaitu pita 5 dan 8 dengan berat molekul $66,2 \mathrm{kD}$ dan $14,6 \mathrm{kD}$, dan lima pita minor yaitu 1, 2, 3, 4 dan 6 dengan berat molekul berturut-turut adalah 133 $\mathrm{kD}, 114,4 \mathrm{kD}, 103,5 \mathrm{kD}, 84,7 \mathrm{kD}$ dan $39,9 \mathrm{kD}$; untuk $5 \mathrm{ml}$ fraksi ke3, setelah dielektroforesis didapatkan tujuh pita protein, terdiri dari dua pita mayor yaitu pita 5 dan 8 dengan berat molekul $66,2 \mathrm{kD}$ dan $14,6 \mathrm{kD}$, dan lima pita minor yaitu 1, 2, 3, 4 dan 6 dengan berat molekul berturut-turut adalah 133 $\mathrm{kD}, 114,4 \mathrm{kD}, 108,8 \mathrm{kD}, 84,7 \mathrm{kD}$ dan $41,9 \mathrm{kD}$; sedangkan untuk 5 $\mathrm{ml}$ fraksi ke-4 setelah dielektroforesis didapatkan lima pita protein, terdiri dari satu pita 
mayor, yaitu pita 8 dengan berat molekul 14,6 kD, dan empat pita minor yaitu 3, 4, 5 dan 6 dengan $\mathrm{BM}$ berturut-turut adalah $103,5 \mathrm{kD}$, $84,7 \mathrm{kD}, 66,5 \mathrm{kD}$ dan $39,9 \mathrm{kD}$.

Hasil elektroforesis tersebut menunjukkan, bahwa isolat albumin perlakuan suhu pengukusan waterbath $40^{\circ} \mathrm{C}$ (suhu daging $36^{\circ} \mathrm{C}$ ), jenis dan kandungan protein yang terlarut dalam isolat albumin masih komplek dan tinggi, hal tersebut terlihat dari banyaknya jumlah dan jelasnya ketebalan pita protein yang terdeteksi setelah dielektroforesis, selain itu tiap-tiap fraksi pengambilan dari kolom filtrasi gel sephadex G-75, setelah dielektroforesis menghasilkan jumlah pita protein yang lebih konstan. Hal tersebut terlihat dari (lajur M, N, O dan P Gambar 11.) keempat fraksi memiliki jumlah pita protein sama yaitu tujuh pita. Diduga keempat fraksi tersebut jumlah kandungan proteinnya hampir sama, sedangkan untuk ketebalan pita terdapat kesamaan untuk pengambilan $5 \mathrm{ml}$ fraksi ke-1 sampai dengan $5 \mathrm{ml}$ fraksi ke-3, masing-masing terdapat dua pita mayor. Diduga ketiga fraksi awal ini muatan berat molekul albuminnya memiliki kadar yang hampir sama.

Widowati dan Wijaya (1997) melaporkan hasil penelitiannya, bahwa pita mayor itu memiliki ketebalan dan intensitas warna yang lebih besar dibandingkan pita-pita lainnya, sehingga berkesimpulan bahwa pita mayor itu merupakan pita protein yang memiliki konsentrasi lebih tinggi dibandingkan dengan pita-pita lainnya (pita minor). Foegeding et al. (1986) menunjukan hasil penelitiannya, pada pemanasan BSA (bovine serum albumin) $40^{\circ} \mathrm{C}$ sampai dengan $70^{\circ} \mathrm{C}$ didapatkan jumlah zone relatif komplek (7 pita) dan dua diantaranya tebal dengan soluble protein berkisar antara 6,5$3,5 \mathrm{mg} / \mathrm{ml}$, tetapi pada pemanasan $80^{\circ} \mathrm{C}$ keatas jumlah zone berkurang drastis (1 pita) dan tipis dengan soluble protein berkisar 1-1,5 $\mathrm{mg} / \mathrm{ml}$. 
myosin $(200,0 \mathrm{kDa})$

$\beta$-galactosidase $(116,3 \mathrm{kDa})$

phosphorylase (97,4 kDa)

bovine scrum albumin $(66,2 \mathrm{kDa})$

ovalbumin $(45,0 \mathrm{kDa})$

carbonic anhydrase (31,0 kDa)

trypsin inhibitor $(21,5 \mathrm{kDa})$

lysozyme $(14,4 \mathrm{kDa})$

aprotinin $(6,5 \mathrm{kDa})$

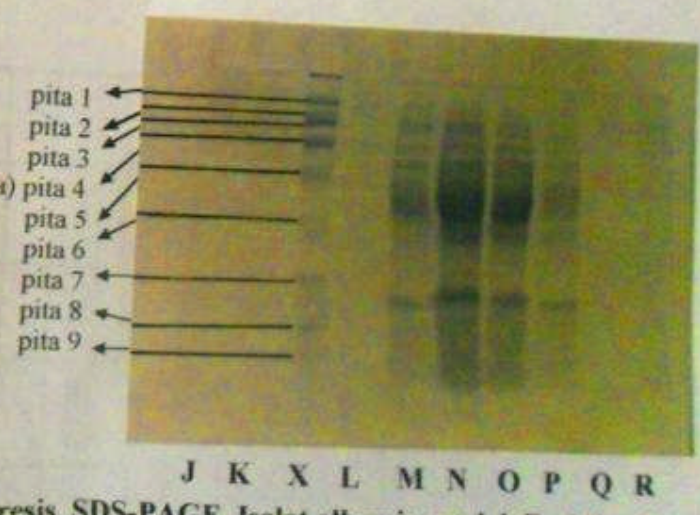

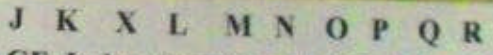

Gambar 3. Hasil Elektroforesis SDS-PAGE Isolat Albumin setelah Fraksinasi

\section{Keterangan :}

$\mathrm{X}=$ kit penciri protein : myosin, $\beta$-galactosidase, phosporylase $\mathrm{B}$, bovine serum albumin, ovalbumin, carbonic anhydrase, trypsin inhibitot, lysozyme dan aprotinin

$\mathrm{J}=$ isolat albumin $5 \mathrm{ml}$ fraksi ke-2 suhu waterbath $90^{\circ} \mathrm{C}\left(\right.$ suhu daging $\left.66^{\circ} \mathrm{C}\right)$

$\mathrm{K}=$ isolat albumin $5 \mathrm{ml}$ fraksi ke-3 suhu waterbath $90^{\circ} \mathrm{C}$ (suhu daging $66^{\circ} \mathrm{C}$ )

$\mathrm{L}=$ isolat albumin $5 \mathrm{ml}$ fraksi ke-4 suhu waterbath $90^{\circ} \mathrm{C}$ (suhu daging $66^{\circ} \mathrm{C}$ )

$\mathrm{M}=$ isolat albumin $5 \mathrm{ml}$ fraksi ke-1 suhu waterbath $40^{\circ} \mathrm{C}$ (suhu daging $36^{\circ} \mathrm{C}$ )

$\mathrm{N}=$ isolat albumin $5 \mathrm{ml}$ fraksi ke-2 suhu waterbath $40^{\circ} \mathrm{C}$ (suhu daging $36^{\circ} \mathrm{C}$ )

$\mathrm{O}=$ isolat albumin $5 \mathrm{ml}$ fraksi ke-3 suhu waterbath $40^{\circ} \mathrm{C}$ (suhu daging $36^{\circ} \mathrm{C}$ )

$\mathrm{P}=$ isolat albumin $5 \mathrm{ml}$ fraksi ke-4 suhu waterbath $40^{\circ} \mathrm{C}$ (suhu daging $36^{\circ} \mathrm{C}$ )

$\mathrm{Q}=$ isolat albumin $5 \mathrm{ml}$ fraksi ke-2 suhu waterbath $90^{\circ} \mathrm{C}$ (suhu daging $66^{\circ} \mathrm{C}$ )

$\mathrm{R}=$ isolat albumin $5 \mathrm{ml}$ fraksi ke-3 suhu waterbath $90^{\circ} \mathrm{C}$ (suhu daging $66^{\circ} \mathrm{C}$ )

Hasil elektroforesis (Gambar sebelumnya (lihat lajur I Gambar 3.) isolate albumin perlakuan suhu 10., lajur J, K dan L Gambar 3.), pengukusan waterbath $90^{\circ} \mathrm{C}$ (suhu pada pengambilan $5 \mathrm{ml}$ fraksi ke-2 daging $66^{\circ} \mathrm{C}$ ), yang merupakan dan ke-3 tidak dihasilkan pita konversi dari perlakuan suhu protein.

pengukusan waterbath $90^{\circ} \mathrm{C}$


Hasil elektroforesis tersebut menunjukan bahwa pada suhu pengukusan waterbath $90^{\circ} \mathrm{C}$ (suhu daging $66^{\circ} \mathrm{C}$ ), yang merupakan hasil konversi dari suhu pengukusan waterbath $90^{\circ} \mathrm{C}$ sebelumnya, ternyata juga punya kecenderungan yang sama pita protein hilang dan tidak terdeteksi (lajur Q dan R Gambar 3.). Hal ini diduga kelarutan protein dalam isolat albumin rusak akibat denaturasi panas, dan terjadinya perubahan sifat karakteristik isolate albumin, yaitu terbentuknya gel. Soepomo (1992), dalam uraiannya mengenai pengolahan daging menyatakan, bahwa semakin tinggi suhu pemasakan dan atau lama waktu pemasakan, makin besar protein yang rusak sampai mencapai tingkat yang konstan sehingga diperoleh hasil sampai cukup rendah. Ilminingtyas dkk. (2000) memaparkan hasil penelitiannya, bahwa perubahan pola protein hasil SDS-PAGE menunjukkan adanya perubahan yang terjadi pada protein, penipisan dan hilangnya pita protein menunjukkan terjadinya perubahan sifat pada protein tersebut.

\section{Kesimpulan}

Kadar albumin isolat albumin tertinggi sebesar $1,77 \mathrm{mg} / \mathrm{g}$, pengaruh suhu pengukusan $40^{\circ} \mathrm{C}$ selama 30 menit, pada pengambilan $5 \mathrm{ml}$ fraksi ke-2. Elektroforesis SDS-PAGE dengan jumlah protein paling komplek adalah isolat albumin pengaruh suhu pengukusan $40^{\circ} \mathrm{C}$ selama 30 menit, terletak pada $5 \mathrm{ml}$ fraksi ke-1, $5 \mathrm{ml}$ fraksi ke-2 dan $5 \mathrm{ml}$ fraksi ke-3. Pita protein terdiri dari 2 pita mayor dan 5 pita minor dengan BM 14,6-133 kD.

\section{Saran}

Berdasarkan hasil terbaik penelitian tersebut diatas, disarankan untuk dilakukan uji kualitas biologis ekstrak albumin kasar dan isolat albumin pada tikus Mencit (Mus musculus L.).

\section{Daftar Pustaka}

Alexander, M.R.; Ambre, J.J.; Liskon, B.I. and D.C. Trash, 1979. Therapeutic Use Of Albumin. JAMA., 241 : 2527 2529.

Arntfield, S. D.; Murray, E. D. and M. A. H. Ismond, 1986. Effect of Salt on the Thermal Stability of Storage Proteins from Fababean (Vice faba). J. Food Sci., 51 : 371-377.

Carvallo, Y. N., 1998. Study Profit Asam Amino, Albumin, Mineral Zn pada Ikan Gabus (Ophiocephalus sriatus) dan Ikan 
(Ophiocephalus

Micropeltus).

Perikanan.

Fakultas

Brawijaya. Malang. Hal 2830.

Foegeding, E. A.; Allen, C. E. and W. R. Dayton, 1986. Effect of Heating Rate on Thermally Formed Myosin, Fibrinogen and Albumin Gels. J. Food Sci., 51 : 104107.

Folawiyo, Y. L. and O. R. K. Apenten, 1996. The Effect of Heat Acid Treatment on The Structure of Rapeseed Albumin (Napin). J. Food Sci., 61 : 237-239.

Hames, B. D. and D. Rickwood, 1990. Gel Electrophoresis of Protein : A Practical Approach. Second Edition. Oxford University Press, New York. Page. 17

Hidayati, O., 1999. Study Kadar Albumin, Zn dan TVB Filtrat Ikan Gabus (Ophiocephalus sriatus) pada Lama Sterilisasi dan Penyimpanan yang Berbeda. Laporan Penelitian.

Fakultas Perikanan. Universitas Malang. Hal 36.

Kato, Y,; Watanabe, K. and Y. Sato, 1981. Effect of
Maillard Reaction on Some Physical Properties of Ovalbumin. J. Food Sci., 62 : 1861-1820.

Martini, N. D., 1998. Pengaruh Lama Pengukusan Terhadap Kandungan Albumin, Asam Amino dan $\mathrm{Zn}$ pada Ikan Gabus (Ophiocephalus sriatus). Laporan Penelitian. Fakultas Perikanan. Universitas Brawijaya. Malang. Hal. 36.

Nakai, S. and H.W. Modler, 1996. Food Proteins Properties and Characterization. Food Science and Technology (Series Editor). American Food and Nutrition Center. Page. 168-224.

Nielsen, S., 1998. Food Analysis. London. Glisers

Raeker, M.O. and Johnson, 1985. Thermal and Functional Properties of Bovine Blood Plasma and Egg White Proteins. J. Food Sci., 60:687

Soemitro, S.; Marianti, L. dan A. Safari, 1992. Percobaan Biokimia Penentuan Struktur Protein. Pusat dan Antar Universitas Bioteknologi. Institut Teknologi Bandung. Hal. 23. 
Soepomo, 1992, Ilmu Teknologi

Daging. Gadjah Mada

University Press. Jogjakarta.

Hal. 20-40.

Sudamadji, S., 1996. Teknik Analisa Biokimiawi.

Jogjakarta. Hal. 97-220.

Suprayitno, E., 2003. Penyembuhan

Luka dengan Ikan Gabus.

Fakultas

Perikanan.

Universitas Brawijaya.

Malang

Sutiman, B. S.; Rahayu, S.;

Fatchyah ; Widyawati, S. dan

E. A, Laras, 1996. Teknik

Biologi Molekuler. Jurusan

Biologi. MIPA Unibraw.

Malang. Hal. 25-90.

Weissler, N. L.; Mangino, M. E.;

Harper, W. J. and R. Raman,
1981. Identification of Serum Albumin in Protein Complexes to Dissociation by Sodium Dodecyl Sulfate. J. Food Sci., 46 : 979-978.

Widowati, S. dan Wijaya, S.K., 1997. Isolasi dan Karakterisasi Globumin 7S dan 11S dari Sepuluh Varietas Kedelai Indonesia. Dalam Budianto, $\mathrm{S}$; Zakaria, $\mathrm{F}$; Hariyadi dan Satiyowiharjo, B (ed). Prosiding Seminar Nasional Teknologi Pangan. Denpasar.

Wirahadikusuma, M., 1981. Biokimia Proteina, Enzima dan Asam Nukleat. Penerbit ITB. Bandung. Hal 26-38. 